\begin{tabular}{|c|c|c|}
\hline 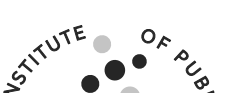 & & (6) (cc) BY-NC \\
\hline - $\frac{1}{n}$ & & Rocz Panstw Zakl Hig 2021;72(2):209-220 \\
\hline 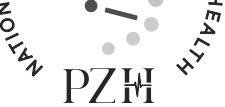 & http://wydawnictwa.pzh.gov.pl/roczniki_pzh/ & https://doi.org/10.32394/rpzh.2021.0166 \\
\hline
\end{tabular}

\title{
DIETARY RECOMMENDATIONS DURING THE COVID-19 PANDEMIC. STATEMENT OF THE COMMITTEE OF HUMAN NUTRITION SCIENCE OF THE POLISH ACADEMY OF SCIENCES ${ }^{*}$
}

\author{
Lidia Wadołowska ${ }^{* 1}$, Małgorzata Drywieñ ${ }^{* 2}$, Jadwiga Hamułka ${ }^{* 2}$, Piotr Socha ${ }^{* 3}$, Maria Borawska*4, \\ Mariola Friedrich ${ }^{* 5}$, Ewa Lange ${ }^{* 6}$ and other Members of the Human Nutrition Science Committee \\ of the Polish Academy of Sciences ${ }^{7}$
}
*Human Nutrition Science Committee, Department of Medical Sciences, Polish Academy of Sciences
${ }^{1}$ Department of Human Nutrition, University of Warmia and Mazury, Olsztyn, Poland
${ }^{2}$ Department of Human Nutrition, Warsaw University of Life Sciences, Warsaw, Poland
${ }^{3}$ Department of Gastroenterology, Hepatology, Eating Disorders and Paediatrics, Institute 'Monument -
Children's Health Center', Warsaw, Poland
${ }^{4}$ Department of Bromatology, Medical University of Bialystok, Białystok, Poland
${ }^{5}$ Department of Applied Microbiology and Human Nutrition Physiology, West Pomeranian University of
Technology in Szczecin, Szczecin, Poland
${ }^{6}$ Department of Dietetics, Warsaw University of Life Sciences, Warsaw, Poland

\begin{abstract}
${ }^{7}$ Stanistaw Berger, Jerzy Bertrandt, Barbara Bobrowska-Korczak, Monika Bronkowska, Ewa Cieślik, Jadwiga Charzewska, Jolanta Czarnocińska, Magdalena Człapka-Matyasik, Anna Dlugosz, Ewa Gayny, Danuta Górecka, Joanna Gromadzka-Ostrowska, Anna Gronowska-Senger, Marzena Jeżewska-Zychowicz, Anna Kotłajtis-Dołowy, Zbigniew Krejpcio, Teresa Leszczyńska, Renata Markiewicz-Żukowska, Zbigniew Marzec, Hanna Mojska, Regina Olędzka, Katarzyna Przybyłowicz, Juliusz Przystawski, Joanna Sadowska, Matgorzata Schlegel-Zawadzka, Katarzyna Socha, Jerzy Socha, Iwona Traczyk, Jarosław Walkowiak, Agata Wawrzyniak, Halina Weker, Marta Widz, Aneta Wojdyło, Małgorzata Woźniewicz, Katarzyna Zabłocka-Słowińska
\end{abstract}

\begin{abstract}
During the COVID-19 pandemic, care for an adequate diet, well adapted to the body's needs and the current level of physical activity, becomes of particular importance. Many dietary compounds participate in the functioning of the immune system, while vitamins D, C, A (including beta-carotene), E, B6, B12, folic acid, zinc, copper, selenium, iron, amino acids, n-3 and n-6 polyunsaturated fatty acids and intestinal microbiota are crucial in various types of defence processes. There has been no evidence that consumed food and its compounds, including those with pro-/prebiotic properties, play a significant role in preventing SARS-CoV-2 infection or alleviating its course. However, in terms of the nutritional value of food and the prevention of dysbiosis, recommending a varied diet with a high proportion of plant-based foods and an adequate amount of animal-based foods has a sound scientific basis. Malnutrition, underweight and obesity are considered independent and prognostic risk factors of severe SARS-CoV-2 infection, which reduce a patient's chances of survival. Therefore, ensuring good nutritional status, including healthy body weight, is a reasonable approach in the prevention of viral infection SARS-CoV-2 or alleviating its course. The document is accompanied by two catalogues of practical nutritional recommendations during the COVID-19 pandemic, addressed to the general population and children.
\end{abstract}

Key words: antiviral properties, breastfeeding, COVID-19, diet, food, immunity, nutrition, pandemic, SARS-CoV-2

\section{STRESZCZENIE}

Podczas pandemii COVID-19 (ang. coronavirus disease 2019) troska o właściwą dietę, dobrze dostosowaną do zapotrzebowania organizmu i aktualnego poziomu aktywności fizycznej, nabiera szczególnego znaczenia. W funkcjonowaniu układu odpornościowego bierze udział wiele składników pochodzących z diety, a znaczenie w różnego typu procesach obronnych mają witaminy D, C, A (w tym beta-karoten), E, B6, B12, kwas foliowy, cynk, miedź, selen,

Corresponding author: Małgorzata Drywień, Katedra Żywienia Człowieka, Szkoła Główna Gospodarstwa Wiejskiego w Warszawie, 02-787 Warszawa, ul. Nowoursynowska159 c, e-mail: malgorzata_drywien@sggw.edu.pl

* These dietary recommendations are also published in Polish on the journal's website and in Stand Med Pediatr 2021;18:289-298

(C) Copyright by the National Institute of Public Health - National Institute of Hygiene 
żelazo, aminokwasy, wielonienasycone kwasy tłuszczowe n-3 i n-6 oraz mikrobiota jelitowa. Obecnie nie ma dowodów, aby spożywana żywność i zawarte w niej składniki, w tym o właściwościach pro-/prebiotycznych, odgrywały istotną rolę W zapobieganiu zakażeniu SARS-CoV-2 (ang. severe acute respiratory syndrome coronavirus 2) i łagodzeniu jego przebiegu. Jednak biorąc pod uwagę wartość odżywczą żywności i zapobieganie dysbiozie, rekomendowanie urozmaiconej diety, z dużym udziałem różnorodnej żywności pochodzenia roślinnego oraz odpowiednią ilością żywności pochodzenia zwierzęcego, ma dobre podstawy naukowe. Niedożywienie, niedowaga i otyłość są rozważane jako niezależne i prognostyczne czynniki ryzyka ciężkiego przebiegu zakażenia SARS-CoV-2, które zmniejszają szanse pacjenta na przeżycie, dlatego dbałość o dobry stan odżywienia, w tym prawidłową masę ciała, jest rozsądnym podejściem w profilaktyce zakażenia SARS-CoV-2 i łagodzeniu jego przebiegu. Do dokumentu dołączono dwa wykazy praktycznych rekomendacji żywieniowych podczas pandemii COVID-19 - skierowane do populacji generalnej oraz do dzieci.

Słowa kluczowe: COVID-19, dieta, karmienie piersia, odporność, pandemia, SARS-CoV-2, właściwościprzeciwwirusowe, żywienie, żywność

\section{INTRODUCTION}

The global pandemic resulting from the infection with SARS-CoV-2 virus has changed all aspects of everyday life, as it has brought about a change in the dietary behaviour and lifestyle for most people, accompanied by an increase in stress experienced due to isolation, drastically reduced social interactions and concerns about contracting the virus, and the loss of employment and income [3,12,15,31]. Adequate nutrition is important to maintain health and, during the COVID-19 pandemic, taking care to follow a balanced diet which is well adapted to the body's needs and the current physical activity level, becomes particularly import ant $[8,9,22,47]$.

\section{Sources of information on nutrition and infection with the SARS-CoV-2 virus}

Identification of nutritional factors associated with a mild, moderate, and severe course of infection with the SARS-CoV-2 virus is the starting point for the development of "good nutritional practices" and the formulation of principles of the prevention and treatment of the infection [42]. There is no doubt that the world has been taken by surprise by the scale of the pandemic and its consequences for human health and lives. Experts were expected to indicate methods for treating the infection and preventing its consequences. However, gathering strong scientific evidence (from randomised experimental studies) takes time, and it is difficult to obtain it within the timeframe of the pandemic.

The dietary recommendations have been developed through modifying the existing, well-documented dietary recommendations [11,16,45,56] and adapting them to the changes in Poles' diets and lifestyles observed during the COVID-19 pandemics and are also based on the following:

- knowledge of physiology and pathophysiology concerning the effects of food and nutrition on the nutritional status of the body and its functioning, including the functions of the immune system.
- evidence gathered prior to the pandemic for other respiratory diseases (e.g. pneumonia) and other viruses (e.g. influenza A and B virus),

- knowledge derived from few experimental studies conducted during the pandemic, usually single-centre studies with small sample sizes, or observational studies that are less powerful in explaining the correlations between the diet, SARS-CoV-2 virus infection, the course of infection and mortality; several large experimental studies in this field are underway, but their results and conclusions have yet to be published.

\section{Changes in the diet and lifestyle during the COVID-19 pandemic}

The available study results $[11,18,21,31]$ show that in Poland, during the three initial months of the pandemic, many adults increased their food intake (34\%) and the time spent in front of a screen (49\%), while reducing their physical activity (43\%). This resulted in an increase in the prevalence of overweight, and in the near future, it may trigger a further increase in the rates of obesity and many of its co-morbidities, e.g. cardiovascular diseases, diabetes and other metabolic diseases and certain types of cancer [39]. However, some adults have reduced their food intake $(14 \%)$, including those with previously normal or too low body weight, thus increasing the problem of the prevalence of underweight, malnutrition and anorectic behaviour.

Such changes in food consumption and lifestyle must be considered a major hazard to public health, especially in the context of overweight and obesity. Before the pandemic, $4-5 \%$ of children aged 2-6 years, $8 \%$ of girls and $14 \%$ of boys of school age were obese (data from the National Health Programme for 2017-2020). Moreover, depending on the age, 4-28\% of adults or the elderly were obese (data from the European Health Interview Survey, 2014) and two to three times as many Poles were overweight $[34,35,46]$. 
The diet, nutritional status and immunity of the body

The foods we eat and the components they are made of determine the body's nutritional status and can affect its ability to prevent and combat infections and promote recovery. Food is a source of approx. 70 nutritional compounds (e.g. amino acids, polyunsaturated fatty acids, glucose, vitamins, and minerals) and many biologically active components (e.g. polyphenols with antioxidant properties) but also anti-nutrients (e.g. phytates, oxalates, and ascorbic acid oxidase, i.e. an enzyme that breaks down ascorbic acid) or even harmful contaminants (e.g. arsenic, benzo(a)pyrene), which together are responsible for the body's health status. Good nutritional status (adequate saturation of tissues with nutrients) is essential for maintaining health and for the proper functioning of all systems and organs of the body, including the immune system.

The immune system protects the body against pathogens (bacteria, viruses, fungi, and parasites) through complex mechanisms in which a variety of specialised cells and regulatory substances are involved [7]. The immune system is active at all times and its activity increases during infection. Increased activity of the immune system is accompanied by an increased metabolic rate and higher consumption of energy and substrates needed for the synthesis of substances and cells involved in defence processes.

Many components derived from the diet are involved in the functioning of the immune system, with the special role in a variety of defence processes served by vitamins $\mathrm{D}, \mathrm{C}$ and $\mathrm{A}$ (including betacarotene), E, B6, B12, folic acid, minerals: zinc, copper, selenium, and iron, amino acids and polyunsaturated $n-3$ and $n-6$ fatty acids [7,42]. The most attention is given to vitamins $\mathrm{D}, \mathrm{C}$, and $\mathrm{A}$ and to zinc, selenium and polyunsaturated $n$ - 3 fatty acids, as they play a crucial role in maintaining the integrity and functions of the immune system, including the activation, differentiation and proliferation of immune cells and in maintaining the stability of cell membranes as the immune response of the body is determined by their interaction at many stages of this process $[7,50,51,58,62]$. These key nutrients have been demonstrated to be of particular importance in supporting the anti-viral and anti-bacterial defence mechanisms of the body, alleviating infection symptoms and reducing the risk of a severe course of "regular" (i.e. non-covid) respiratory infections $[5,7,23-25,28,29,36,40,41,52,53,60,66]$. On this basis, their beneficial effect on the course of SARS-CoV-2 virus infection can be predicted and the ongoing clinical trials will help explain the role of nutrients in the treatment of this viral infection [2,7]. Currently, a discussion is underway on the possibility of the therapeutic use of vitamins $\mathrm{C}, \mathrm{D}$ and $\mathrm{A}$, as well as zinc and polyunsaturated $n-3$ fatty acids, in amounts not exceeding the upper tolerable intake levels (including the components derived from the diet) as a low-cost, pharmacological way to potentially help prevent infection with the SARS-CoV-2 virus or reduce its effects $[42-44,48,63]$

It is also the bacteria and other microorganisms found in the large intestine of humans (the so-called intestinal microbiota) that serve an important role in regulating immune system functions. The presence of a large number of probiotic microorganisms (e.g. Bifidobacterium, Lactobacillus) has a beneficial effect on many functions in the intestine and the whole body, including through the formation of a physical and chemical barrier that protects the large intestine against colonisation by pathogenic microorganisms and the probable strengthening of the body's innate immunity $[7,32,37,42,59]$. Diet is one of the major factors determining the composition of the intestinal microbiota. A disturbed composition of the intestinal microbiota (dysbiosis) is seen in people with a high intake of animal-based foods and a low intake of plantbased foods. Conversely, a favourable composition of the intestinal microbiota is found in people who eat more plant-based foods, including those regularly consuming prebiotic foods that contain shortchain oligosaccharides (e.g. onion, garlic, legumes, whole-grain cereal products from oats or wheat) and fermented foods containing lactic acid bacteria (e.g. yoghurt, kefir, acidophilus milk and fermented vegetables) $[7,32,37,42,59,64]$. Two systematic reviews with meta-analysis $[37,64]$ have recently confirmed that probiotic microorganisms in adults enhanced the body's immune response to seasonal influenza vaccination. Moreover, a disturbed composition of the intestinal microbiota (dysbiosis) has been demonstrated in patients with a severe course of infection with the SARS-CoV-2 virus.

At present, there is no evidence that the foods consumed and the components they contain, including those with pro- and prebiotic properties, serve an important role in preventing infection with the SARSCoV-2 virus and alleviating its course [7,49,59]. However, taking into account the nutritional value of foods and the prevention of dysbiosis, recommending a diversified diet containing a high proportion of plant-based foods and an appropriate amount of animal-based foods has a solid scientific foundation.

\section{Malnutrition, obesity and infection with the SARS- CoV-2 virus}

Nutritional deficiencies (overt or hidden malnutrition), generalised or relating to single components (e.g. vitamins C and D, B-group vitamins, zinc, selenium, iron, protein), reduce the body's 
immunity and can therefore increase the risk of falling ill and worsen the course of several diseases. Thus, it is logical that any weakening of the immune system's defensive function, including malnutrition, is conducive to infection with the SARS-CoV-2 virus. On the contrary, a balanced diet that fully covers the human body's requirement for all nutrients can support the functioning of the immune system, including in the course of infection with the SARS-CoV-2 virus.

This view is supported by the results from observational studies. It was found that deficiencies of zinc, selenium and vitamin $\mathrm{C}$ or $\mathrm{D}$ were several times more common in patients with a severe course of infection with the SARS-CoV-2 virus than in noninfected individuals or patients with a mild course of infection with this virus [7,42]. Almost $50 \%$ of patients hospitalised for COVID-19 infection were malnourished [4,42]. Furthermore, in patients with general malnutrition, primary or secondary (resulting from a disease, hospitalisation or therapy applied), a more severe course of infection and higher mortality due to COVID-19 have been demonstrated. An analogous observation concerned underweight or obese patients, which indicates the need to maintain a sustainable energy balance and a normal body weight regardless of the need for adequate saturation of the tissues with nutrients. Experts of the European Society for Clinical Nutrition and Metabolism [4] (ESPEN) published (in 2020) their position containing an unequivocal recommendation stating that the prevention, diagnosis and treatment of malnutrition should be routinely applied in the treatment of patients with COVID-19 and that elderly patients and those with multiple other diseases should be given special care to ensure their adequate nutritional status.

Obesity is considered an independent and prognostic risk factor for a severe course of infection with the SARS-CoV-2 virus, which reduces a patient's chances of survival $[4,38,42,65]$. Coexistent malnutrition may be a cause of poor prognosis for obese people, as excessive body fat does not exclude the occurrence of nutrient deficiencies, particularly in people with an unhealthy diet or those who have repeatedly followed popular but harmful weight-loss diets. Obesity and infection with the SARS-CoV-2 virus share some similarities, as they exacerbate inflammatory processes in the body, which may take a particularly drastic course in infection with this virus. In a severe course of the SARS-CoV-2 virus infection, a critical response of the body occurs, referred to as the "cytokine storm", resulting from the activation of specific defence cells (macrophages) found in greater numbers in the adipose tissue $[7,42,38,65]$. Such a scenario has been described in the infection with the H1N1 influenza virus and is currently being considered for the infection with the SARS-CoV-2 virus [7,26].
Irrespective of the results of future research, avoiding overweight and obesity should undoubtedly be considered a reasonable approach in the prevention of infection with the SARS-CoV-2 virus and alleviating its course.

\section{Food, its components and infection with the SARS- CoV-2 virus}

In many products that are documented to be historically consumed by humans and have been used in traditional medicine, the presence of substances with anti-inflammatory, anti-fungal, anti-bacterial or antiviral properties was demonstrated, e.g. vitamin $C$ in fruits/juice of raspberries or elderberries, hesperidin, kaempferol and methylglyoxal in bee honey, allicin in garlic and onions, gingerols in ginger, curcumin in turmeric, piperine in pepper, etc $[1,6,10,13,27,54$, 55,57].

There is, however, no strong scientific evidence, let alone systematic literature reviews with meta-analysis, indicating that specific foods (including herbs, herbal infusions and spices) or specific food components with anti-viral, anti-bacterial, and anti-inflammatory properties, or dietary supplements are responsible for the prevention, alleviation of symptoms or treatment of the SARS-CoV-2 virus infection, including the severe covid pneumonia, acute respiratory syndrome, the "cytokine storm", blood clotting disorders and organ failure leading to Heath $[4,7,38,42,65]$. Currently, such an association is considered to be potential and is a valuable hypothesis that requires evidence from the highest-quality experimental studies and awaits a quantitative summary in systematic literature reviews with meta-analysis.

In view of the above and of the likely health benefits, despite the lack of strong evidence, there is currently no justification for advising against the consumption of foods containing substances with anti-inflammatory, anti-bacterial or anti-viral properties. However, daily or frequent consumption of these foods should not lead to drastic changes in the diet composition and to worsening of the diet balance due to having excluded other foods containing crucial nutrients.

Therefore, the previously developed nutritional recommendations referring to the general population and population groups with special needs remain valid. Given that children, adolescents, the elderly and pregnant or breastfeeding women are at greater risk of nutrient deficiencies and the resulting adverse health effects, ensuring the good nutritional status of these population groups is a reasonable approach in the prevention of infection with the SARS-CoV-2 virus. 


\section{COVID-19 pandemic and general dietary recommendations}

During the COVID-19 pandemic, care must be taken to achieve and maintain optimal nutritional status of the body, including a normal body weight, by providing with the diet all the nutrients needed by the body in amounts appropriate to the age, sex, physiological state and physical activity, in accordance with the dietary recommendations [30], if the individual needs of the body are not known.

The general principle of balanced nutrition is to consume a varied diet based on available foods. A key nutritional strategy for supporting the body and immune system functions should be a diet containing an adequate amount of water, a high proportion of plant-based foods (vegetables, fruit, whole-grain cereal products, legumes, nuts, and seeds), and an adequate amount of foods of animal origin (fish, dairy products, eggs and meat products) $[8,9,22,42,47]$.

A variety of fresh and non-processed or minimally processed food products that provide vitamins, nutrients, dietary fibre, protein, polyunsaturated $n-3$ and $n-6$ fatty acids and antioxidant components (e.g. polyphenols, carotenoids) should be consumed daily. Foods high in sugar, salt and saturated fatty acids should be avoided, to significantly reduce the risk of overweight, obesity, cardiovascular diseases, diabetes and certain types of cancer

\section{GENERAL DIETARY RECOMMENDATIONS DURING THE COVID-19 PANDEMIC}

1. Ensure that the energy value of the diet is adjusted to the current level of physical activity

2. Half of the daily dietary intake should be based on vegetables and fruit

3. Maintain adequate hydration of the body

4. Make reasonable food purchasing

5. Reduce sugar, salt and fat intake

6. Avoid drinking alcohol

7. Follow the principles of hygiene and safe food handling

8. Consume home-cooked meals in company as a method of stress relief

9. Ensure regular physical activity

10. Use dietary supplementation if the diet fails to meet the body's requirements

11. Use reliable sources of nutrition information

Table 1. General dietary recommendations during the COVID-19 pandemic

1. Ensure that the energy value of the diet is adjusted to the current level of physical activity

- Eat a variety of foods, as each food product has a different nutritional value. When choosing food, it is advisable to be guided by the "Healthy eating plate" and to find the right balance between the plant-based and animal-based foods

- The daily diet should contain a wide variety of vegetables, fruit, whole-grain cereal products, legumes, nuts, and seeds and an adequate amount of fish, dairy products, eggs and meat products

- The diet should be based on low-energy foods with low fat and sugar contents

- It is advisable to choose foods with a low glycaemic index ${ }^{1}(\mathrm{GI}<50)$, which can prolong the feeling of satiety and reduce the energy value of meals while contributing to the normalisation of blood glucose levels and having a positive effect on the regulation of fat metabolism

- If you are a sedentary worker, do not overeat or go on a fasting diet in order to maintain or achieve a normal body weight

- If you are underweight or overweight, do not skip meals, eat regularly, try to regulate your daily rhythm, and ensure adequate length and quality of sleep

2. Half of the daily diet should be based on vegetables and fruit

- Eat at least five servings of vegetables and fruit every day, with a predominance of vegetables (3-4 servings of vegetables, and 1-2 servings of fruit)

- Choose raw vegetables and fruit, or minimally processed vegetables (e.g. briefly cooked or steamed) from a variety of colours

3. Maintain adequate hydration of the body

- Drink at least 8-10 glasses of unsweetened beverages every day

- Preferably, drink either water or fruit or herbal infusions

- To improve the flavour of your water, add a piece of fresh, aromatic fruit or some fresh herbs

- Eating fresh fruit and vegetables also helps maintain adequate hydration

- Reduce your intake of caffeine-containing beverages, as too much caffeine intake (e.g. more than 3-4 cups of coffee a day) can promote dehydration and impair the quality of sleep 
4. Make reasonable food purchasing

- Food shopping should be well planned and done according to a pre-prepared list of products that are actually needed

- The food shopping list should include products that have run out or which need to be replenished, with attention being paid to their shelf-life

- It is recommended to buy fresh products and those with a shorter shelf-life, e.g. vegetables, fruit and dairy products

- Where it is necessary to use foods requiring longer storage, the best solution is frozen foods whose nutritional value is very close to that of fresh products

- Freezing can also be a good way to make reasonable use of the food bought or prepared in too large quantities

5. Reducing sugar, salt and fat intake

Sugar

- Choose fresh, frozen or dried fruit without added sugars rather than sweets

- If you do eat sweets, choose those with a lower sugar content and added fruit rather than cream and limit consumption

- Pay attention to the fat content in sweets - read the nutrition information on labels

- Reduce the amount of sugar or honey added to dishes and drinks and substantially reduce or give up the consumption of sweetened beverages

Salt

- Reduce or eliminate adding salt to dishes when cooking and, at the table, remove the saltshaker from the table

- Salt can be successfully replaced with herbs and spices, or alternatively, with low-sodium salt

- Reduce the intake of ready-made cold cuts and meat products. Instead, eat fish and use lean meats prepared by yourself at home, with spices and a reduced amount of salt

- Limit or avoid the use of ready-made sauces (e.g. soy and fish sauces), stocks, soups and instant meals in favour of self-prepared dishes seasoned with little salt

- Choose unsalted nuts and seeds for snacks

Fat

- Choose lean meats and cold cuts and trim excess fat off fatty meats

- Limit traditional frying, or replace it with other cooking techniques that require no addition of fat, or low-fat techniques (e.g. baking or low-fat stewing)

- Reduce your intake of processed, high-fat dairy products, e.g. processed cheese, cream cheeses and spreads

- Remember that vegetable and animal fats have various nutritional values but the same energy value $(9 \mathrm{kcal} / \mathrm{gram})$, so, regardless of the type of fat, a high fat intake is conducive to obesity

6. Avoid drinking alcohol

- Alcohol impairs the functioning of the nervous system and reduces the immune system's response to infection

- Isolation and limited social interactions can contribute to abnormal habits associated with alcohol drinking - avoid situations that encourage drinking alcoholic beverages

- Increased alcohol consumption, especially by people who are overweight or obese, or have cardiovascular diseases or diabetes, increases the likelihood of a severe course of COVID-19 infection

- Alcohol consumption increases the symptoms of depression and anxiety

- Alcohol can reduce the efficacy, or increase the effects and toxicity of certain medications

- Do not consume alcoholic beverages during the prevention or treatment of COVID-19 infection

7. Follow the principles of hygiene and safe food handling

- Wash food product packages after bringing them home, if possible

- Thoroughly wash foods intended for raw consumption, particularly vegetables and fruit

- Follow basic rules of hand, kitchen and dish hygiene

- Keep raw and cooked foods separately at safe temperatures, preferably below $5^{\circ} \mathrm{C}$

- Thermally process (at above $60^{\circ} \mathrm{C}$ ) foods that require it

8. Consume home-cooked meals in company as a method of stress relief

- Try to prepare meals together with your household members or friends using instant messaging

- Have meals together with your household members or friends using instant messaging, at fixed times, in a calm and relaxed atmosphere

- If you eat home-delivered, ready-made meals, pay attention to proper hygienic conditions during their transport and delivery and observe the "use by" date

9. Ensure regular physical activity

- If possible, try to take a walk every day

- Do physical exercises adapted to the abilities and conditions on a regular basis

- When doing sedentary work, do short relaxing exercises to change your body position 
10. Use dietary supplementation if the diet fails to meet the body's requirements

- The use of dietary supplements should be targeted at supplementing the body's deficiencies in the nutrient that is lacking in the diet

- If a routine vitamin D supplementation is recommended, adhere to the regimen

- Using other dietary supplements containing vitamins or minerals, especially those containing selenium, should always be consulted with and supervised by your doctor

- Certain vitamins and minerals, if taken in excess, can have an adverse effect on health (more information to be found in the Position of the Committee of Human Nutrition Science of the Polish Academy of Sciences on dietary supplements)

11. Use reliable sources of nutrition information

- During the pandemic, a lot of unconfirmed or distorted information on the effects of dietary factors on infection with the COVID-19 virus and the severity of its course has emerged, with the World Health Organization (WHO) referring to this problem of media disinformation as an "infodemic"

- When searching for nutrition information, make sure that it is written by expert teams, preferably linked to academic circles, scientific societies or recognised institutions (e.g. WHO) and that it is confirmed by documented references to the results of scientific studies that have been published in renowned scientific journals

- In situations requiring nutritional advice, seek help from a specialist: a dietitian or nutritionist.

'The glycaemic index is used to describe the body's response and the increase in blood glucose levels after eating food or a meal containing carbohydrates. For example, natural muesli, milk, natural yoghurt, fruit and vegetable juices, nuts, seeds, vegetables, fresh and dried legume seeds, and most fresh and dried fruit have a low glycaemic index $(\mathrm{GI}<50)$.

\section{The COVID-19 pandemic and dietary recommendations for children \\ During the COVID-19 pandemic, children and} adolescents are subject to the same nutritional requirements as adults. Periods of their growth and development, in which potential malnutrition can have long-term health consequences, are considered to be crucial [14,17]. It is therefore important to provide the growing body with an adequate amount of all nutrients, with particular emphasis on vitamin $\mathrm{D}[30,56]$.

For infants up to six months of age, exclusive breastfeeding should be promoted as optimal to their health and development [56]. To date, no presence of replicating SARS-CoV-2 has been demonstrated in breast milk, while protective antibodies have been found in it $[19,33,61]$. SARS-CoV-2 virus infection confirmed in a mother is not a contraindication for breastfeeding the child. However, since recommendations on breastfeeding in the context of SARS-CoV-2 virus infection may change as new data become available, it is important to check them regularly, e.g. on the website of the Polish Neonatal Society (www.neonatologia.edu.pl).

As new food products are introduced to a young child's daily diet, it is essential to offer a variety of fresh and non-processed or minimally processed food to provide water, all nutrients and dietary fibre in amounts appropriate to the child's age and needs [56].

A particular concern with of Polish children at various ages is the continuous increase in the prevalence of obesity [34,35], which is expected to rise, particularly during the pandemic due to lower physical activity resulting from online learning, extended time spent in front of a computer screen and the restrictions on movement and social interactions. Therefore, for the sake of physical, mental and social health, it is essential to promote daily physical activity within the limits permitted by epidemiological regulations $[12,15,20]$.

\section{DIETARY RECOMMENDATIONS FOR CHILDREN DURING THE COVID-19 PANDEMIC}

1. Breastfeeding

2. Make sure to drink enough water every day

3. Ensure regular physical activity

4. Provide fresh and unprocessed or minimally processed foods

5. Provide fats of adequate quality

6. Reduce salt and sugar intake

7. Prepare home-cooked meals

8. Use psychosocial support and help from specialists 
Table 2. Dietary recommendations for children during the COVID-19 pandemic

1. Breastfeeding

- Breastfeeding should be initiated as early as possible, preferably within two hours after birth and continued for the first six months of the child's life as exclusive feeding; then, until at least two years of age, complementary foods with no sugars or salt added should be introduced systematically during the second half of the year of the child's life, in accordance with the current guidelines of the national team of paediatric experts

- If COVID-19 infection is confirmed or suspected in a mother, wear a face mask near the baby, wash your hands thoroughly with soap or disinfectant before and after contact with the baby and routinely clean and disinfect all the surfaces being touched

- During a severe course of the COVID-19 infection in a mother, or in the case of complications that restrict direct breastfeeding, breastmilk can be expressed to ensure the baby has a continuous supply of breast milk if the mother's health allows it

- If, however, breastfeeding is not possible, consideration should be given to the possibility of resuming breastfeeding after a pause or using breast milk from a milk bank

2. Make sure to drink enough water every day

- A child should drink several cups of water every day (the recommended daily water intake is 1-2.5 litres, including water from foods)

- Water is the most suitable liquid, but other drinks (e.g. unsweetened milk) and vegetables and fruit containing a lot of water (e.g. cucumbers, tomatoes, spinach, melons, broccoli, Brussels sprouts, oranges, apples and berries) can be given to children as well

- Avoid giving children sweetened beverages (e.g. fruit drinks, syrups, fruit juice concentrates, fizzy and still drinks) as they contain sugar(s)

- Fruit juices can be given to children over one year of age, but in limited amounts (no more than $1 / 2-1$ glass depending on the child's age)

3. Ensure regular physical activity

- Ensure that your child takes daily walks and plays outdoors

- Exercise together with your child on a regular basis, adapting the physical exercises to the abilities and conditions

- Control the amount of time your child spends in front of a computer or TV screen and limit it to the necessary minimum, especially if learning takes place in front of a screen

4. Provide fresh and non-processed or low-processed foods

- Every day, provide your child with vegetables, fruit, legumes (e.g. lentils, beans), low- or non-processed cereal products (e.g. coarse groats, oat and wheat flakes, maize), potatoes, nuts, and animal-based foods (e.g. meat, fish, eggs, dairy products) in quantities adapted to his/her age and nutrient requirements

- If you use ready-made meals (e.g. jarred or canned) or dried vegetables and fruit, choose those with no or little salt and sugars added

- Give your children raw vegetables and fresh fruit as snacks

5. Provide fats of adequate quality

- A child should eat unsaturated fats, e.g. found in fish, avocado, nuts, olive oil, rapeseed, sunflower and maize oil rather than saturated fats, e.g. found in fatty meat, lard and coconut oil

- Give your child dairy products in the recommended quantities (e.g. milk, fermented milk drinks, butter, cream, cheeses and cottage cheese), as they are a source of vitamins D, A, and B2 as well as beneficial fatty acids and cholesterol which is essential during the early stages of development

- Provide your child with various types of lean meat and fish rather than ready-made cold cuts that contain lots of fat and salt

- Do not give your child highly processed foods (e.g. fast food meals, ready-to-eat snacks, fried dishes, frozen pizzas, cakes, cookies or cubed margarine), as they contain industrially produced trans-fatty acids

6. Reduce salt and sugar intake

- Reduce daily salt intake from any sources to less than $5 \mathrm{~g}$ (approx. 1 teaspoonful) and use iodised salt

- When preparing meals for your child, reduce the amount of salt and high-sodium condiments (e.g. soya or fish sauces)

- Do not give your child high-salt or sugar snacks (e.g. salty sticks, salted nuts, cookies or sweets)

- Do not give your child drinks with a high sugar content (e.g. fruit drinks, fruit concentrates and syrups, flavoured milk and milk drinks) 


\begin{tabular}{|l|}
\hline 7. Prepare home-cooked meals \\
\hline - Prepare meals at home to improve the quality of your family's diet, as home-cooked food tend to be healthier and more \\
nutritious for young and growing children than restaurant meals or industrially prepared food which may contain \\
excessive amounts of salt, fats and sugars and can be high in calories \\
- Eating out during the COVID-19 pandemic increases contact with other people and the chance of being infected \\
- Involve children in choosing food and preparing meals together \\
\hline 8. Use psychosocial support and help from specialists \\
\hline - If you feel insecure or overwhelmed by the responsibilities involved in feeding your children, seek psychosocial \\
support from family and friends and specialist advice from a psychologist, dietitian or nutritionist \\
\hline
\end{tabular}

\section{SUMMARY}

This document is supplemented by two lists of recommendations addressed to the general population (Table 1) and to children (Table 2), which provide a detailed overview of practical nutritional recommendations for the population in Poland during the COVID-19 pandemic.

\section{REFERENCES}

1. Al-Hatamleh M.A.I., Hatmal M.M., Sattar K., Ahmad S., Mustafa M.Z., Bittencourt M.C., Mohamud R.: Antyviral and immunomodulatory effects of phytochemicals from honey against COVID-19: potential mechanisms of action and future directions. Molecules 2020;25:5017. doi:10.3390/molecules 25215017

2. Asher A., Tintle N.L., Myers M., Lockshon L., Bacareza H., Harris W.S.: Blood omega-3 fatty acids and death from COVID-19: A pilot study. Prostaglandins, Leukotrienes and Essential Fatty Acids 2021;166:102250. doi:10.1016/j.plefa.2021.102250

3. Balanzá-Martínez V., Atienza-Carbonell B., Kapczinski F., De Boni R.B.: Lifestyle behaviours during the COVID-19-Time to connect. Acta Psychiatr. Scand. 2020;141:399-400. doi:10.1111/acps.13177

4. Barazzoni R., Bischoff S.C., Breda J., Wickramasinghe K., Krznaric Z., Nitzan D., Pirlich P., Singer P.. ESPEN Council. ESPEN expert statements and practical guidance for nutritional management of individuals with SARS-CoV-2 infection. Clinical Nutrition 2020;39(6):1631-1638. doi:10.1016/j.clnu.2020.03.022

5. Bergman P., Lindh Åsa U., Björkhem-Bergman L., Lindh J.D.: Vitamin D and respiratory tract infections: a systematic review and meta-analysis of randomized controlled trials. PLoS One 2013;8:e65835 doi:10.1371/ journal.pone.0065835.

6. Bodagh M.N., Maleki I., Hekmatdoost A.: Ginger in gastrointestinal disorders: A systematic review of clinical trials. Food Sci. Nutr. 2019;7:96-108. doi:10.1002/fsn3.807

7. Calder P.C.: Nutrition, immunity and COVID-19. BMJ Nutr. Prev. Health 2020;3:e000085. doi:10.1136/ bmjnph-2020-00008

8. Coronavirus disease (COVID-19) advice for the public. World Health Organization, 2020. Dostęp online: https://www.who.int/emergencies/diseases/novelcoronavirus-2019/advice-for-public
9. Coronavirus disease (COVID-19): Food safety and nutrition. World Health Organization, 2020. Dostęp online: https://www.who.int/emergencies/diseases/ novel-coronavirus-2019/question-and-answers-hub/q-adetail/coronavirus-disease-covid-19-food-safety-andnutrition

10. Cory H., Passarelli S., Szeto J., Tamez M., Mattei J.: The role of polyphenols in human health and food system: a mini-review. Front. Nutr. 2018;5:87. doi:10.3389/ fnut.2018.00087

11.Drywień M.E., Hamulka J., Zielinska-Pukos M.A., Jeruszka-Bielak M., Górnicka M.: The COVID-19 Pandemic Lockdowns and Changes in Body Weight among Polish Women. A Cross-Sectional Online Survey PLifeCOVID-19 Study. Sustainability. 2020; 12(18):7768. doi:10.3390/su12187768

12.Epidemiology Working Group for NCIP Epidemic Response, Chinese Center for Disease Control and Prevention. [The epidemiological characteristics of an outbreak of 2019 novel coronavirus diseases (COVID-19) in China]. Zhonghua Liu Xing Bing Xue Za Zhi. 2020;41(2):145-151. Chinese doi:10.3760/cma.j. issn.0254-6450.2020.02.003

13. ESCO report: Advice on the EFSA guidance document for the safety assessment of botanicals and botanical preparations intended for use as food supplements, based on real case studies. ESCO Working Group on Botanical Preparations. EFSA Journal 2009;7(9):280. doi:10.2903/j.efsa.2009.280

14. Feeding babies and young children during the COVID-19 outbreak. World Health Organization, 2021. Dostęp on-line: https://www.emro.who.int/nutrition/ nutrition-infocus/feeding-babies-and-young-childrenduring-the-covid-19-outbreak.html

15. First meeting of the Technical Advisory Group on the mental health impacts of COVID-19 in the WHO European Region. Virtual meeting, 23 February 2021, Copenhagen: WHO Regional Office for Europe; 2021. Dostęp online: https://apps.who.int/iris/bitstream/ handle/10665/340714/WHO-EURO-2021-2198-4195357643 -eng.pdf?sequence $=1 \&$ isAllowed $=y$

16. Food-based dietary guidelines. Food and Agriculture Organization of the United States, 2020. Dostęp online: http://www.fao.org/nutrition/education/food-dietaryguidelines/en/

17. Genoni G., Conio A., Binotti M., Manzoni P., Castagno M., Rabbone I., Monzani A.: Management and Nutrition of Neonates during the COVID-19 Pandemic: A Review of the Existing Guidelines 
and Recommendations. Am J Perinatol. 2020; 37(S 02):S46-S53. doi:10.1055/s-0040-1714675

18. Górnicka M., Drywień M.E., Zielinska M.A., Hamułka $J$. Dietary and Lifestyle Changes During COVID-19 and the Subsequent Lockdowns among Polish Adults: A Cross-Sectional Online Survey PLifeCOVID-19 Study. Nutrients 2020; 12(8):2324. doi:10.3390/ nu12082324

19. GroßR., Conzelmann C., MüllerJ.A., StengerS., Steinhart K., Kirchhoff F., Münch J. Detection of SARS-CoV-2 in human breastmilk. Lancet. 2020;395(10239):17571758. doi:10.1016/S0140-6736(20)31181-8. Erratum in: Lancet. 2020;396(10253):758.

20. Guidelines on physical activity, sedentary behaviour and sleep for children under 5 years of age. Geneva: World Health Organization; 2019. Dostęp online: https://apps.who.int/iris/bitstream/ handle/ $10665 / 311664 / 9789241550536$-eng. pdf? sequence $=1 \&$ isAllowed $=\mathrm{y}$

21. Hamulka J., Jeruszka-Bielak M., Górnicka M., Drywień M.E., Zielinska-Pukos M.A. Dietary supplements during COVID-19 outbreak. Results of Google trends analysis supported by PLifeCOVID-19 online studies. Nutrients 2021;13:54. doi:10.3390/nu13010054

22. Healthy at home: Healthy diet. World Health Organization, 2020. Dostęp online: https://www. who.int/campaigns/connecting-the-world-to-combatcoronavirus/healthyathome/healthyathome---healthydiet

23. Hemilä $H$. Zinc lozenges and the common cold: a metaanalysis comparing zinc acetate and zinc gluconate, and the role of zinc dosage. JRSM Open 2017; 8:205427041769429. doi:10.1177/2054270417694291

24.Hemilä H., Chalker E. Vitamin C for preventing and treating the common cold. Cochrane Database Syst. Rev. 2013:CD000980. doi:10.1002/14651858.CD000980. pub4

25.Hemilä H., Louhiala P. Vitamin C for preventing and treating pneumonia. Cochrane Database Syst. Rev. 2013:CD005532. doi:10.1002/14651858.CD005532.pub3

26.Honce R., Schultz-Cherry S. Impact of obesity on influenza A virus pathogenesis, immune response, and evolution. Front. Immunol. 2019;10:1071. doi:10.3389/ fimmu.2019.01071

27. Hosseinzade A., Sadeghi O., Naghdipour Biregani A., Soukhtehzari S., Brandt G.S., Esmaillzadeh A.: Immunomodulatory Effects of Flavonoids: Possible Induction of $\mathrm{T}$ CD4+ Regulatory Cells Through Suppression of mTOR Pathway Signaling Activity. Front. Immunol. 2019;10:51. doi:10.3389/fimmu.2019.00051

28.Hu N., Li Q-B., Zou $S$-Y.: Effect of vitamin A as an adjuvant therapy for pneumonia in children: a metaanalysis. Zhongguo Dang Dai Er. Ke.ZaZhi2018;20:146153. doi:10.7499/j.issn.1008-8830.2018.02.013

29. Imdad A., Mayo-Wilson E., Herzer K., Bhutta Z.A. Vitamin A supplementation for preventing morbidity and mortality in children from six months to five years of age. Cochrane Database Syst. Rev. 2017;3:CD008524. doi:10.1002/14651858.CD008524.pub3
30.Jarosz M., Rychlik E., Stoś K., Charzewska J. (red.). Normy żywienia dla populacji Polski i ich zastosowanie. Wydawnictwo NIZP-PZH, Warszawa 2020.(In Polish)

31. Jeżewska-Zychowicz M., Plichta M., Królak M.: Consumers' Fears Regarding Food Availability and Purchasing Behaviors during the COVID-19 Pandemic: The Importance of Trust and Perceived Stress. Nutrients 2020;12(9): 2852. doi:10.3390/nu12092852

32. Kaur H., Agarwal S., Agarwal M., Agarwal V., Singh M.: Therapeutic and preventive role of functional foods in process of neurodegeneration. IJPSR, 2020; 11(6):28822891. doi:10.13040/IJPSR.0975-8232.11(6).2882-91

33.Kirtsman M., Diambomba Y., Poutanen S.M., Malinowski A.K., Vlachodimitropoulou E., Parks W.T., Erdman L., Morris S.K., Shah P.S.: Probable congenital SARS-CoV-2 infection in a neonate born to a woman with active SARS-CoV-2 infection. CMAJ 2020;192(24):E647-E650. doi:10.1503/cmaj.200821

34.Kułaga Z., Kotowska A., Gorzkowska B., Stolarczyk A, Kowalkowska J., Wadołowska L., Socha P.: Narodowy Program Zdrowia: Raport końcowy $\mathrm{z}$ realizacji projektu „Przeprowadzenie kompleksowych badań epidemiologicznych dotyczących sposobu żywienia i stanu odżywienia społeczeństwa polskiego ze szczególnym uwzględnieniem małych dzieci, wraz zidentyfikacją czynników ryzyka zaburzeń odżywiania, oceną poziomu aktywności fizycznej, poziomu wiedzy żywieniowej oraz występowania nierówności w zdrowiu”. Maszynopis, Instytut „Pomnik-Centrum Zdrowia Dziecka". Warszawa 2021.

35. Kułaga Z., Kotowska A., Gorzkowska B., Stolarczyk A., Kowalkowska J., Wadołowska L., Socha P.: Narodowy Program Zdrowia: Raport końcowy $\mathrm{z}$ realizacji projektu „Przeprowadzenie kompleksowych badań epidemiologicznych dotyczących sposobu żywienia i stanu odżywienia społeczeństwa polskiego ze szczególnym uwzględnieniem dzieci i młodzieży w wieku szkolnym, wraz z identyfikacją czynników ryzyka zaburzeń odżywiania, oceną poziomu aktywności fizycznej, poziomu wiedzy żywieniowej oraz występowania nierówności w zdrowiu". Maszynopis, Instytut „Pomnik-Centrum Zdrowia Dziecka". Warszawa 2021.

36.Lassi Z.S., Moin A., Bhutta Z.A.: Zinc supplementation for the prevention of pneumonia in children aged 2 months to 59 months. Cochrane Database Syst. Rev. 2016;12:CD005978. doi:10.1002/14651858.CD005978. pub3

37. Lei W-T., Shih P-C., Liu S-J., Yeh T-L.: Effect of probiotics and prebiotics on immune response to influenza vaccination in adults: a systematic review and meta-analysis of randomized controlled trials. Nutrients 2017;9:1175. doi:10.3390/nu9111175

38. Liang T. Handbook of COVID-19 prevention and treatment, 2020. Dostęp online: https://www.alnap.org/ help-library/handbook-of-covid-19-prevention-andtreatment

39. Lippi G., Henry B.M., Sanchis-Gomar F.: Physical inactivity and cardiovascular disease at the time of coronavirus disease 2019 (COVID-19). 
Eur. J Prevent. Cardiol. 2020;27(9):906-908. doi:10.1177/2047487320916823

40.Mao S., Zhang A., Huang S.: Meta-Analysis of Zn, Cu and $\mathrm{Fe}$ in the hair of Chinese children with recurrent respiratory tract infection. Scand. J Clin. Lab. Invest. 2014;74:561-567. doi:10.3109/00365513.2014.921323

41. Martineau A.R., Jolliffe D.A., Hooper R.L., Greenberg L., Aloia J. .F, Bergman P. et al.: Vitamin D supplementation to prevent acute respiratory tract infections: systematic review and meta-analysis of individual participant data. BMJ 2017;356:16583. doi:10.1136/bmj.i6583

42. Mentella M.C., Scaldaferri, Gasbarrini A., Miggiano G.A.D.: The role of nutrition in the COVID-19 pandemic. Nutrients 2021;13:1093. doi:10.3390/nu13041093

43. Mercola J., Grant W.B., Wagner C.L. Evidence Regarding Vitamin D and Risk of COVID-19 and Its Severity. Nutrients 2020;12:3361. doi:10.3390/ nu12113361

44.Name J.J., Souza A.C.R., Vasconcelos A.R., Prado P.S., Pereira C.P.M.: Zinc, Vitamin D and Vitamin C: Perspectives for COVID-19 With a Focus on Physical Tissue Barrier Integrity. Front. Nutr. 2020;7:606398. doi:10.3389/fnut.2020.606398

45. Narodowe Centrum Edukacji Żywieniowej: Zalecenia zdrowego żywienia. Dostęp online: https://ncez.pl/ upload/nowe-zalecenia-zywieniowe.pdf

46. Odsetek osób w wieku powyżej 15 lat według indeksu masy ciała (BMI). Główny Urząd Statystyczny 2020. Dostęp online: https://stat.gov.pl/obszary-tematyczne/ zdrowie/zdrowie/odsetek-osob-w-wieku-powyzej-15lat-wedlug-indeksu-masy-ciala-bmi,23,1.html

47. Pal A., Squitti R., Picozza M., Pawar A., Rongioletti M., Dutta A.K., Sahoo S., Goswami K., Sharma P., Prasad R.: Zinc and COVID-19: Basis of Current Clinical Trials. Biol. Trace Elem. Res. 2020;1-11. doi:10.1007/ s12011-020-02437-9

48. Pascoal L.B., Rodrigues P.B., Genaro L.M., et al.: Microbiota-derived short-chain fatty acids do not interfere with SARS-CoV-2 infection of human colonic samples. Gut Microbes 2021;13(1):e1874740. Doi:10.108 0/19490976.2021.1874740

49. Pillai R., Uyehara-Lock J.H., Bellinger F.P. Selenium and selenoprotein function in brain disorders. IUBMB Life, 2014;66(4):229-239. doi: 10.1002/iub.1262

50.Pludowski P., Holick M.F., Grant W.B., Konstantynowicz J., Mascarenhas M.R., Haq A., Povoroznyuk V., Balatska N., Barbosa A.P., Karonova T., et al.: Vitamin D supplementation guidelines. J. Steroid Biochem. Mol. Biol. 2018; 175:125-135. doi: 10.1016/j.jsbmb.2017.01.021

51. Q\&A on coronaviruses (COVID-19). World Health Organization, 2020. Dostęp online: https://www.who. int/news-room/q-a-detail/q-a-coronaviruses

52.Ran L., Zhao W., Wang J., Wang H., Zhao Y., Tseng $Y$., Bu H. Extra Dose of Vitamin C Based on a Daily Supplementation Shortens the Common Cold: A MetaAnalysis of 9 Randomized Controlled Trials. Biomed Res. Int. 2018;2018:1837634. doi:10.1155/2018/1837634

53. Science M., Johnstone J., Roth D.E., Guyatt G., Loeb M.: Zinc for the treatment of the common cold: a systematic review and meta-analysis of randomized controlled trials. Can. Med. Assoc. J. 2012;184:E551561. doi:10.1503/cmaj.111990

54.Semwal R.B., Semwal D.K., Combrinck S., Viljoen A.M.: Gingerols and shogaols: Important nutraceutical principles from Ginger. Phytochemistry 2015;117:554568. doi: 10.1016/j.phytochem.2015.07.012

55. Stojanovic-Radic Z., Pejcic M., Dimitrijevic M., Aleksić A. V., Anil Kumar N., Saleh, B. C., Cho W., Sharifi-Rad, $J$.: Piperine - a major principle of black pepper: a review of its bioactivity and studies. Appl. Sci. 2019;9;4270. doi.org/10.3390/app9204270

56.Szajewska H., Socha P., Horvath A., RybakA., Bartłomiej M. Zalewski, Nehring-Gugulska M., Mojska H., Czerwionka-Szaflarska M., Gajewska D., Ewa Helwich, Jackowska T., Ksiażyk J., Lauterbach R., OlczakKowalczyk D., Weker H.: Zasady żywienia zdrowych niemowląt. Stanowisko Polskiego Towarzystwa Gastroenterologii, Hepatologii i Żywienia Dzieci. Standardy Medyczne 2021. Dostęp online: https:// ptghizd.pl/cm/uploads/2020/12/Karmienie-piersia.pdf

57. Turck D., Castenmiller J., De Henauw S., et al.: EFSA NDA Panel (EFSA Panel on Nutrition, Novel Foods and Food Allergens),., 2019. Scientific Opinion on the safety of phenylcapsaicin as a novel foodpursuant to Regulation (EU) 2015/2283. EFSA Journal 2019;17(6):5718. doi:10.2903/j.efsa.2019.5718

58. Uwitonze, A.M., Razzaque, M.S.: Role of Magnesium in Vitamin D Activation and Function. J. Am. Osteopath. Assoc. 2018;118:181-189. doi:10.7556/jaoa.2018.037

59. Vignesh R., Swathirajan C.R., Tun Z.H., Rameshkumar M.R., Solomon S.S., Balakrishnan P.: Could perturbation of gut microbiota possibly exacerbate the severity of COVID-19 via cytokine storm? Front. Immunol. 2021;11:607734. doi:10.3389/fimmu.2020.607734

60. Wang L., Song Y.: Efficacy of zinc given as an adjunct to the treatment of severe pneumonia: a meta-analysis of randomized, double-blind and placebo-controlled trials. Clin. Respir. J. 2018;12:857-864. doi:10.1111/crj.12646

61. Wesolowska A.: Karmienie piersią i mlekiem matki a ryzyko infekcji wirusowej SARS-CoV-2 u dziecka w obliczu pandemii COVID-19. Postępy Neonatologii 2020;1(26):9-15.

62. Wierzejska R.: Witamina D a COVID-19. Aktualny stan wiedzy. Dostęp online: https://ncez.pl/abc-zywienia-/ zasady-zdrowego-zywienia/witamina-d--a-covid-19-aktualny-stan-wiedzy

63.Xu Y., Baylink D.J., Chen C.S., Reeves M.E., Xiao J., Lacy C., Lau E., Cao H.: The importance of vitamin $\mathrm{d}$ metabolism as a potential prophylactic, immunoregulatory and neuroprotective treatment for COVID-19. J. Transl. Med. 2020;18(1):322. doi:10.1186/ s12967-020-02488-5

64.Yeh T-L., Shih P-C., Liu S-J., Lin C-H., Liu J-M., Lei $W-T$., Lin $C$-J.: The influence of prebiotic or probiotic supplementation on antibody titers after influenza vaccination: a systematic review and meta-analysis of randomized controlled trials. Drug Des Devel Ther 2018;12:217-230. doi:10.2147/DDDT 
65. Zalecenia diagnostyki i terapii zakażeń SARS-CoV-2 Polskiego Towarzystwa Epidemiologów i Lekarzy Chorób Zakaźnych z dnia 13 października 2020. Aneks 2 do rekomendacji z 31 marca 2020. Med. Prakt. 2020;11:51-69. Dostęp online: http://www.pteilchz. org.pl/wp-content/uploads/2020/10/Aneks-2-doRekomendacji-PTEiLChZ-13-10-2020-pl.pdf
66.Zhou Y.F., Luo B.A., Qin L.L.: The association between vitamin $\mathrm{D}$ deficiency and communityacquired pneumonia: a meta-analysis of observational studies. Medicine 2019;98:17252. doi:10.1097/ MD.0000000000017252

Received: 14.05 .2021

Accepted: 20.05.2021 